Relations industrielles

Industrial Relations

\title{
III - Reform of Enterprise
}

\section{The Problems Which Present Themselves}

\section{Marcel Clément}

Volume 3, numéro 7, mars 1948

URI : https://id.erudit.org/iderudit/1023609ar

DOI : https://doi.org/10.7202/1023609ar

Aller au sommaire du numéro

Éditeur(s)

Département des relations industrielles de l’Université Laval

ISSN

0034-379X (imprimé)

1703-8138 (numérique)

Découvrir la revue

Citer cet article

Clément, M. (1948). III - Reform of Enterprise: The Problems Which Present

Themselves. Relations industrielles / Industrial Relations, 3(7), 110-112.

https://doi.org/10.7202/1023609ar

Tous droits réservés @ C Département des relations industrielles de l’Université Laval, 1948
Ce document est protégé par la loi sur le droit d'auteur. L'utilisation des services d'Érudit (y compris la reproduction) est assujettie à sa politique d'utilisation que vous pouvez consulter en ligne.

https://apropos.erudit.org/fr/usagers/politique-dutilisation/ 


\section{The Problems...}

(Continued from page 112)

is the team that works against. In an enterprise when the feeling of solidarity is confined to the workmen and the management gives the impression of standing apart from the group, the inevitable result is the formation of a group on the defensive which, in order to defend itself (since feeling itself not liked it consequently feels itself threatened) becomes necessarily a group against.

On the contrary, if the feeling of solidarity in labour extends to all the members of the enterprise, it is really a "community 》 which is formed in response to the basic requirement of man to be linked up with those who surround him. When this community plunges its roots deep into the supernatural life it becomes a communion. Thus one sees what the modern world might be were it organized along Christian lines and so bearing visible witness to the doctrine of the Mystic Body.

It is the depths of man's nature itself, his religious feeling, that is to say, his craving to be united (religare) which clearly designates the community within the enterprise as the one formula capable of realizing harmoniously the primary unit of economic life.

\section{II}

In order to set up the community within the enterprise, first of all the employer must « become spiritually a new man and the foremost workman amongst his workers ». ${ }^{2}$ It is really upon this interaction of mind and spirit that all adequate reform of structure is based. This change once secured, the problem of the «intention 》 is solved. It is necessary, consequently, to designate the concrete problems to be worked out, in other words, to specify around what visible tokens the community will be established. Practically, the three problems of the community of ownership, the community of profit and the community of authority, present themselves.

A-The community of ownership is a theme which inspired in Jacques Maritain the following lines: «with the progress of economic organization a new right for the technically and socially qualified workman made its appearance - the right to work. This right guaranteed the worker that his job was really his, assured to him personally by legal claim and this his working activity would be safe-guarded. »

This text assumes what is traditionally called the mastery of a trade. If the employer is at one and the same time owner of the means of production and, by that same fact, master of his position as employer, the workman in turn, if he be dependant only on the law of the supply and demand

(2) Bulletin des relations industrielles. Vol. III, no 5. of labour is not master of his employment. From this it follows that it is never a question of mistaking ownership of a trade and ownership of the means of production. Particularly in the case of a business of a personal character, the ownership of the means of production is not only legimate but necessary and good. But always this ownership should be completed by the accepted or legal guarantees able to give to the worker the certitude that his trade is his own, that a stability compatible with his personal dignity is assured him and that, finally, no one can avail himself of a position for which he has not the requisite training.

From another point of view it is wise to remember that the right of ownership is never absolute. Its usage is never morally legitimate not politically fruitful unless it is put to the service of the entire community of labour.

B-The community of profit forms the focus of the interests which are grouped in general under the name of Structural Reform. To the extent in which Capital and Labour are part of the same community the fruits of their efforts should be apportioned between the two. According to R. Kothen ${ }^{3}$ here is how moralists view the division of shares:

a) Each party has a right to his « restitutio in intregum » i.e. capital should be repayed and labour should be remunerated in strict fairness.

b) As to the surplus, it should be divided by giving a percentage interest to capital invested paid out of profits, and another share of the profits should be assigned to labour.

Such is the principle. Such are the requirements of a really humane economy. We will examine later on in detail the different practical solutions which have been proposed - profit-sharing, bonuses, proportionate wage, independent shifts, industrial co-partnership, etc.

C-The community of authority remains the most difficult problem to be dealt with if one would be both impartial and tactful. On the one hand it is certain that there should be but one central authority. Anything else spells anarchy. On the other hand, this authority should not ignore systematically, or even by simple oversight, the reactions and the counsels of those over whom it is exercised. According to the size of the enterprise, according to whether it has the character of a family-owned business or of a limited company, according, finally, to the extent of the maturity, of its union members, different formulae can be imagined from the simple workmen's delegation to the joint production committee. In this sphere form is of less importance than the spirit that animates it. The end to be attained is the permiting of frequent exchanges between the personnel of 


\section{SALAIRES GARANTIS ${ }^{1}$}

Nous croyons utile, à titre documentaire, de reproduire les conclusions auxquelles est arrivé le Comité sénatorial chargé, sous la direction de monsieur Murray W. Latimer, d'étudier aux Etats-Unis la question des salaires garantis:

\& Le Comité agrée unanimement les conclusions suivantes du rapport et ses implications:

1-Les programmes portant sur les salaires garantis ne devraient pas être adoptés par voie législative mais ètre plutôt référés à la libre négociation collective;

2-La stabilité de l'emploi et sa réalisation par des salaires ou des emplois garantis, là où c'est possible, sont des matières qui doivent intéresser mutuellement les employeurs et les employés. Chaque partie a la responsabilité définie de chercher à stabiliser les opérations au sein d'une usine ou d'un établissement en vue d'accroître le niveau de la sécurité économique générale de la nation;

3-La réalisation de la stabilité par l'adoption de salaires garantis est affectée dans son progrès par les législations existantes dans les domaine de l'assurance sociale, des salaires minima, de la politique fiscale et de la taxation, pour ne nommer que ceux-là. Conséquemment. il est essentiel de reviser et d'évaluer les programmes préconisés pour en constater les correlations afin de les ordonner tous au but fixé: la détermination de conditions stables d'emploi;

4-Le salaire garanti a une grande importance mais ne doit pas être considéré comme un moyen pouvant suffire à lui seul à établir la stabilité et le sécurité économique nationale.

5-Le besoin est urgent d'établir la stabilité économique à travers tout le pays car cette stabilité est essentielle au bien-être national et à la réalisation de la sécurité et de la paix mondiale. Mais puisque le salaire garanti est l'un des facteurs pouvant contribuer à éliminer les fluctuations dans l'industrie et dans l'embauchage, on doit en poursuivre l'étude en vue d'agrandir le champ de la connaissance en ce domaine. De plus, les organismes gouvernementaux devraient fournir à ceux qui s'intéressent à cette question des salaires garantis les informations et les données nécessaires à la poursuite efficace de leur travail.

Le rapport soulève un certain nombre de questions relatives à la politique nationale et industrielle qui ne nécessitent pas de réponse catégorique. Nous recommandons que le gouvernement accorde sans relâche à ces questions une attention coordonnée ainsi qu'à tout ce qui se rapporte aux programmes de salaires garantis.

Nous recommandons également que la responsabilité de la direction de l'intégration des efforts gouvernementaux incombe au Comité d'aviseurs économiques qui, dans l'exécution de leurs fonctions, devront rencontrer ou consulter les autres intéressés ainsi qu'il est prévu dans la loi organique du Comité. »

(1) Guaranteed wages, Report to the President by the Advisory Board, U.S. Government Printing Office, Washington, 1947, page XVIII.

\section{The Problems...}

(Continued from page 110)

management and the personnel of labour in an atmosphere of mutual confidence.

Community of ownership in their trade, community of profits resulting from a common effort, community of authority by loyalty to a management that is tempered by the spirit of collaboration - such are the reforms to bring about within the enterprise. The first and the last points result in the main from an attitude. The second presupposes the choice of a technique. It is to the study of this second consideration that we shall devote the next article in this series.

\section{GUARANTEED WAGES}

We believe it useful, for documentary purposes, to reproduce the conclusions of the Report of the Advisory Board, under the direction of Mr. Murray W. Latimer, charged in the United States with the study of the question of guaranteed wage plans:

\& The Board unanimously shares the following conclusions concerning the report an its implications:

1-Adoption of guaranteed wage plans should not be the subject of legislative action, but should be referred to free collective bargaining;

2-Stabilization of employment and its effectuation through wage or employment guarantees, wherever possible, are matters of mutual concern to employers and employees. Each party has the definite responsibility of seeking to stabilize operations within a plant or industry in order to advance the level of general economic security of the Nation;

3-Progress toward the achievement of stability through the institution of guaranteed wages is affected by existing legislation in the fields of social insurance, minimum wages, fiscal and tax policies,. among others. Consequently, it is essential to review and evaluate all such programs to ascertain their interrelationships, with a view to coordinating all to the end of attaining stable employment conditions;

4-The guaranteed wage is a significant, but not an all-sufficient, tool which may be employed in building national economic security and stability;

5-There is urgent need for achieving Nation-wide economic stability so essential to our national welfare and to the establishment of world security and peace. Since the guaranteed wage is one of the instruments for the elimination of industrial and employment fluctuations, continuing study to advance the frontiers of knowledge in this area should be undertaken. In addition, Govern ment agencies should provide data and information to those interested in wage guarantees.

The report raises a number of questions of national and industrial policy which do not admit of categorical answers. We recommend that the Government give continuing coordinated attention to these policy questions and other phases of guaranteed wage plans.

We recommend further that responsibility for assuming the leadership in integrating Government efforts be assigned to the Council of Economic Advisers with the understanding that they will consult with and call upon other agencies concerned, as provided in the Council's basic law. »

\section{NOS COLLABORATEURS}

Clément, Marcel, licencié ès lettres, diplômé d'études supérieures de philosophie (Sorbonne), licencié en droit, diplômé d'études supérieures d'économie politique (Faculté de droit de Paris), professeur à la Faculté des sciences sociales de Laval.

Després, Jean-Pierre, docteur en sciences sociales, membre du personnel du Bureau international du Travai à Genève, professeur à la Faculté des sciences sociales de Laval.

Munzer, Egbert, docteur en droits civil et public, ancien membre du ministère de l'Economique du Reich allemand; plus tard professeur à l'université de SaintFrançois-Xavier à Antigonish et statisticien à l'université de Toronto; maintenant professeur à la Faculté des sciences sociales de Laval. 


\title{
THE PROBLEMS WHICH PRESENT THEMSELVES
}

\author{
Marcel CLEMENT
}

By the mechanism of the «liberal » structure such as we have analyzed it in a previous article ${ }^{1}$, the entrepreneur, when he encounters no impediment, is constrained to avoid the two prongs of the pincers (wages and profits) as, in the reverse sense, the wage-earnerconsumer must avoid being caught between the crushing jaws of low salaries and high prices. Even when trade-union organizations and collective agreements impose a limit to such a mechanism, the relations of Capital and Labour within the enterprise remain solely those of buyer and seller. Therefore, when a smoothly functioning trade-union organization creates the conditions necessary for social justice (fair wages, reasonable hours, etc.) one last step has to be taken within the enterprise itself. It, the enterprise, must cease being solely a labour market and become, progressively, a labour community.

We will examine, in turn, first the psychological and social needs to which such a transformation will respond, and, secondly, the problems which will develope within the enterprise as a result of this transformation.

\section{I}

The chief problem to solve is, briefly, that of breaking with a regime which subjugates man to economic forces instead of making economic forces subject to man. Fundamentally, this is the need which will be answered by the setting up of true "communities of enterprise ».

In fact, it is a fundamental need of man that he be assigned a particular place in the society in which he lives.

A-This is essential first of all to satisfy the demands of his intellectual life. In the same way that we discover by faith the meaning of our existence in this world, and that without that knowledge the human spirit is in distress, so also man desires to know why he works in this particular moment of history and in this particular point of space. He longs to be conscious of his place and of his role, to acquire the certitude that there is a secret accord deep and real between his personal aptitudes and his professional destiny. It is therefore necessary that, even in his working hours, the wage-earner should take cognizance of himself, in a spiritual sense, as a member of the Mystic Body; that he should consider himself, at the same time co-operator in the work of creation and collaborator in the work of redemption.

B-The worker should, besides, be so situated in his profession or trade as to satisfy the demands of his emotional life. Actually, there is only one sort of unhappy being on this earth - he who is without ties of affection, who is not loved. No feeling is more depressing than to live in an environment where one does not feel at home. And one can only feel really at home when surrounded by love or at least by friendship. It is evident that such conditions are fulfilled within an enterprise only as the ties binding employers and employees have another basis but that of self interest.

C-Finally, the worker should be so placed within the enterprise as to satisfy the demands of his working life. In the deepest sense of the word collaboration means the possibility of breaking the « solitude of work ». It is above all in action that man experiences the joys of team-work. But, there are two kinds of team. There is the team that works for; there

* The translation of those articles are due to the courtesy of Mrs. Isabel Bancroft.

(1) Bulletin des relations industrielles. Vol. III, no 6.

(Continued on page 110)

\section{A UNIQUE OPPORTUNITY TO GET TOGETHER!}

\section{3rd INDUSTRIAL RELATIONS CONGRESS Tarmes of employer-employee ca-aperation Château Frontenac, Quebec April 19th and 20th 1948 HAVE YOU REGISTERED ?}

